Abstracta Iranica Abstracta Iranica

Revue bibliographique pour le domaine irano-aryen

Volume 34-35-36 | 2017

Comptes rendus des publications de 2011-2013

\title{
Y. Hassanzadeh, H. Mollasalehi. «New Evidence for Mannean Art: An Assessment of Three Glazed Tiles from Qalaichi (Izirtu)»
}

\section{Astrid Nunn}

\section{(2) OpenEdition \\ Journals}

Édition électronique

URL : http://journals.openedition.org/abstractairanica/41431

DOI : 10.4000/abstractairanica.41431

ISSN : 1961-960X

Éditeur :

CNRS (UMR 7528 Mondes iraniens et indiens), Éditions de l'IFRI

Référence électronique

Astrid Nunn, «Y. Hassanzadeh, H. Mollasalehi. «New Evidence for Mannean Art: An Assessment of Three Glazed Tiles from Qalaichi (Izirtu) »», Abstracta Iranica [En ligne], Volume 34-35-36 | 2017, document 5, mis en ligne le 15 juillet 2016, consulté le 30 septembre 2020. URL : http://journals.openedition.org/ abstractairanica/41431 ; DOI : https://doi.org/10.4000/abstractairanica.41431

Ce document a été généré automatiquement le 30 septembre 2020.

Tous droits réservés 


\title{
Y. Hassanzadeh, H. Mollasalehi. " New Evidence for Mannean Art: An Assessment of Three Glazed Tiles from Qalaichi (Izirtu)»
}

\author{
Astrid Nunn
}

\section{RÉFÉRENCE}

Y. Hassanzadeh, H. Mollasalehi. « New Evidence for Mannean Art: An Assessment of Three Glazed Tiles from Qalaichi (Izirtu) », in : Javier Álvarez-Mon, Mark B. Garrison, eds., Elam and Persia. Winona Lake, Eisenbrauns, 2011, p. 407-417.

Les AA. reconsidèrent les fameuses plaques glaçurées fouillées clandestinement dans les années 1970 et 1980 sur le site de Qalāyčī (également dénommé Būkān, Iran du nordouest) et qui furent éparpillés de par le monde. Puisant dans les textes assyriens, les AA. évoquent l'histoire des Mannéens puis décrivent des caractéristiques artistiques de trois plaques seulement. Ils essaient ensuite de définir leur origine. Alors que la tradition artistique de ces plaques est souvent considérée comme étant assyrienne ou urartéenne, les AA. la définissent comme mannéenne et la voient affiliée à un groupe stylistique que l'on pourrait nommer le "Zagros artistic style" développé autour de 1000 av. J.-C. Ces plaques ornaient un temple à l'origine. 


\section{AUTEURS}

\section{ASTRID NUNN}

Université de Munich 